\title{
The Existence of Subsistence, Semi-Commercial and Commercial Urban Agriculture in Bandung Metropolitan, Indonesia
}

\author{
Kinanti Indah Safitri ${ }^{1 *}$, Oekan S. Abdoellah ${ }^{2}$, Yusep Suparman ${ }^{3}$, Akhmad Zainal Mubarak $^{1}$, Margareth $^{1}$ \\ ${ }^{1}$ Graduate Studies on Environmental Sciences, Universitas Padjadjaran, Bandung 40132, Indonesia \\ ${ }^{2}$ Department of Anthropology, Faculty of Social and Political Sciences, Universitas Padjadjaran, Bandung 40132, Indonesia \\ ${ }^{3}$ Department of Statistics, Faculty of Mathematics and Natural Science, Universitas Padjadjaran, Bandung 40132, Indonesia
}

Corresponding Author Email: kinanti19001@mail.unpad.ac.id

https://doi.org/10.18280/ijsdp.160803

Received: 9 September 2021

Accepted: 17 November 2021

Keywords:
subsistence,
commercial, urban agriculture

\begin{abstract}
Urban agriculture provides food supply for urban communities. Recently, urban agricultural output has shifted from domestic to international trade commodities. The specialization of urban agriculture reflects this phenomenon into subsistence, semi-commercial, and commercial agriculture. In this research, we used a qualitative research method with the descriptive approach. We collected data through observation, in-depth interviews, and documentation. The study interviewed 50 people from farmer groups at subsistence, semicommercial, commercial, and local government levels in Bandung Metropolitan. The findings indicated that each category had distinct characteristics and motivations for implementing urban agriculture. We found subsistence urban agriculture in intra-city areas such as Bandung City and Cimahi City as a scheme to reduce dependence on food supplies from other regions. Semi-commercial and commercial agriculture were found in Bandung Regency, West Bandung Regency, and Sumedang Regency. Semi-commercial urban agriculture has two functions: economic development and food production for households or groups. Meanwhile, commercial urban agriculture tried to maximize profit from high-capital turnover. Commercial urban agriculture has a target market to fulfill product demand from supermarkets and exports. The existence of urban agriculture in Bandung Metropolitan needed to be accompanied by policy instruments in sustainable agricultural management to concretize sustainable development goals (SDGs).
\end{abstract}

\section{INTRODUCTION}

Urban agriculture has been developed as the solution to overcome multidimensional problems in urban areas. It relates to social, environmental, and economic functions in implementing urban agriculture activities [1]. Urban agriculture has become a global agenda recommended by FAO to improve the food security of urban communities. Through its Special Program for Food Security (SPFS), FAO coordinates with decision-makers across member countries in strengthening national capacity for the development of policies and strategies related to urban and suburban agriculture and their integration with the National Program for Food Safety.

Urban agriculture is not the only alternative solution for urban communities' needs, but also the problem-solver for urban poverty because of increasing urbanization. In the monetary crisis of the 1980 s, the urban poor were the entities who had difficulty, which affected their ability to provide food security for households [2]. One effort to solve the urbanization problem is internalizing urban agricultural activities to increase employment in the city [3]. The typology of residents who urbanize cities tends to be accustomed to agricultural activities [4, 5]. Therefore, urban agriculture has been developed since the late 1970s in many countries [6]. On the environmental aspect, urban agriculture has a positive impact on urban greening [7], an increase in the urban microclimate [8], the protection of soil, biodiversity, water, and cultural landscapes $[9,10]$. In addition, urban agriculture contributes to solving the problems by converting urban waste into productive resources [9]. Urban agriculture is the concept of utilizing organic waste from vegetables and household food. The reuse of urban organic waste can reduce actual urban problems related to municipal solid waste disposal. The organic waste can be processed into fertilizers which can be replaced by using hazardous chemical fertilizers in the long term and prevent soil degradation in urban agricultural areas [9].

However, urban agricultural activities have become program innovations that are facing a shift in goal orientation. The economic function of urban agriculture is a new opportunity for communities to improve their sources of income. The condition is the transition from subsistence to commercial orientation as a global phenomenon in various countries, including countries in Southeast Asia [11]. The existence of commercialization in agriculture has become an essential strategy for solving poverty and improving the household food security of farmers in low-income countries since the 1980s [12].

The commercialization of urban agriculture has led to the differentiation of types of agriculture based on marketorientation level. Agricultural production systems are 
classified into three categories, namely: subsistence, semicommercial, and commercial [13]. Three types of urban agriculture can be found in countries such as Cuba and Canada. In Cuba, urban agriculture is not only for subsistence production but also for commercial activity based on resources and input costs $[14,15]$. In Southeast Asia countries, many people are involved in urban agricultural activities in the intensive production of durable and high-value commodities [16].

The emergence of urban agriculture commercialization feared the negative impact. This condition is related to resources in the city that reach high prices and the impact of agricultural pollution produced [1]. Limited urban resources lead to fierce competition between policymakers and local actors. In addition, the emergence of the boom and bust cycle of commercialized agriculture can destroy cash crops, alienation, dispossession, farmer household disparities, marginalization of farmers, and adverse environmental consequences [11, 17-21].

In commercial agriculture, farmers must exert structural and technical strength to implement large-scale food production and impact energy and chemicals that damage the environment [22]. Thus, it is feared that urban agriculture will produce very complex dynamic problems when the internalization of economic functions penetrates modern agricultural practices. Therefore, studies on identifying three typologies of urban agricultural models based on market-orientation level, especially in developing countries, and the motives behind the emergence of three models of urban agriculture are needed. Research on subsistence, semi-commercial and commercial agriculture has been carried out in various countries [23-29].

However, the study of agricultural characteristics that have been carried out focused more on agricultural models based on the market-orientation level in rural areas. On the other hand, rural and urban agriculture are distinct concepts with distinct traits and approaches. Additionally, research on the existence of three urban agricultural models classified according to their market orientation is extremely scarce, particularly in Indonesia. We employed a variety of factors based on Pingali and Rosegrant [13] such as farmer's objectives, sources of inputs, product mix, and household income sources [13] (Table 1). Based on several issues that have been presented above, this paper aims to answer the research question "how is the existence of urban agriculture models in Bandung Metropolitan?". Bandung Metropolitan is located in the Upper Citarum Watershed. The Citarum Watershed is a strategic area to support national energy security but, on the one hand, has a critical status in the upstream [30]. The Upper Citarum Watershed has environmental pollution issues due to industrial, agricultural, livestock, and domestic waste [31].

Consequently, the Citarum River has received the label of the world's most polluted river [31]. Optimization of urban agricultural output on a commercial scale can exacerbate the detrimental impact of pollution on the Upper Citarum Watershed area. Therefore, this research is essential because it is located in an area prone to environmental degradation problems. This research can be utilized as a basis for developing strategic plans to resolve environmental issues, particularly in the Upper Citarum Watershed. In order to control the environmental impact of the agricultural sector, it is necessary to identify the characteristics of urban agriculture comprehensively. Thus, this research will serve as a starting point for developing environmentally friendly urban agricultural policies and benefiting urban farmers economically.

Table 1. The characteristics of urban agriculture based on level of market orientation

\begin{tabular}{cccc}
\hline & & Level of Market Orientation \\
\hline & Subsistence & Semi-Commercial & Commercial \\
Farmer's objective & Food self-sufficiency & Surplus generation & Profit Maximization \\
Sources of Inputs & Household generated (non-traded) & Mix of traded and non-traded inputs & Predominantly traded inputs \\
Product Mix & Wide range & Moderately specialized & Highly specialized \\
Household Income Sources & Predominantly Agricultural & Agricultural and non-agricultural & Predominantly non-agricultural \\
\hline
\end{tabular}

\section{LITERATURE REVIEW}

Urban agriculture is the production of agricultural products (crops and livestock) in urban and suburban areas for food and other purposes associated with the transportation, processing, and selling of agricultural products and non-agricultural services prepared by urban farmers [9]. Urban agriculture is a practice that takes place within or on the outskirts of cities where non-agricultural resources are available [32]. Many literatures mention the term urban gardening, and some literature mention urban agriculture. Urban gardening usually connotes leisure, aesthetics, recreation, and a small scale, dominated mainly by women [33]. While urban agriculture is closely correlated with production for subsistence or commercial purposes, it is also associated with livelihood and way of life and is generally more expansive than gardening [33].

In developing countries, urban agriculture grew to respond to the economic consequences of structural adjustment programs in the 1980s [3]. The SAP policy was a form of the southern state's commitment to international loans to overcome the crisis in the 1980s [34]. The implementation of neoliberal policies and SAP, as well as high levels of corruption within the upperclass society, resulted in a severe deterioration of the productive and social sectors [35]. The economic crisis led to a boost in low-income countries' foreign exchange earnings. One way is to increase agricultural exports in rural areas and encourage urban societies to grow crops for their own consumption [3].

While urban agriculture is considered a solution for meeting urban food needs and reducing reliance on rural food supplies, urban agriculture is subject to a variety of external forces that result in changes in many aspects of activity and scale [36]. These external pressures come from urban structures and functions such as resource scarcity, population pressure, climate change, and environmental effects (urban heat island) [36].

Therefore, the development of urban agriculture in various countries has shown a change in subsistence orientation to commercial. The phenomenon of shifting orientation has made 
urban agricultural activities increasingly classified based on production scale and market orientation. Pearson et al. [36] divided the scale of urban agricultural production into three types: the micro-scale, the meso-scale, and the macro-scale [36]. Van Veenhuizen and Danso [16] have also classified urban agriculture into several types: subsistence-based urban agriculture, multifunctional-based urban agriculture, and commercial-based urban agriculture [16]. In addition, the changing of agricultural characteristics results from the agriculture sector being divided into several models based on the market orientation scale. According to Pingali and Rosegrant [13], agricultural characteristics based on the level of market orientation can be classified into three categories, namely: Subsistence, semi-commercial, and commercial [13].

Three urban agriculture models can be seen from the purpose or motive of farmers [13]. Actors who carry out subsistence farming have the purpose of fulfilling household consumption needs independently. Actors in semi-commercial agriculture want surplus generation for the sustainability of their organization. Meanwhile, commercial agricultural actors seek maximum profit from optimizing the sale of their crops to exceed the production costs that they invest in. We used the classification of urban agriculture based on market-orientation because it was relevant to the phenomenon of urban agriculture in Bandung Metropolitan, which was also experiencing commercialization.

Urban agriculture in Bandung Metropolitan at the beginning of its development was used to meet the food needs of the urban population so that food dependence on rural areas could be minimized. However, some urban farmer actors in Bandung Metropolitan realized that their food production could be intensive to become a new opportunity for economic improvement. Thus, urban agriculture activities became increasingly distinct because of a transition from householdscale production toward market-oriented production for profit. Categorizing urban agriculture according to its market orientation would better represent the diverse characteristics of urban agriculture in Bandung Metropolitan, particularly on target, input sources, product mix, and household income sources. The development of these four aspects could produce distinct patterns in urban agriculture's economic, social, and environmental functions.

\section{MATERIALS AND METHOD}

\subsection{Site selection}

The research was conducted in Bandung Metropolitan, consisting of five areas: Bandung Regency, West Bandung Regency, Cimahi City, Bandung City, and parts of Sumedang Regency, West Java Province, Indonesia (Figure 1). Bandung Metropolitan is a remarkable development region with an area of $3,313.08 \mathrm{~km}^{2}$. The reason for choosing the research location was that Bandung Metropolitan followed the classification of urban agriculture divided into intra-urban agriculture and periurban agriculture. In intra-urban areas, a lot of empty land is underutilized. Thus, urban agriculture (roadside, boundary between residential and industrial areas) and unused public or private property might be converted (reserved for future use). The intra-urban areas in Bandung Metropolitan include: Bandung City and Cimahi City. Meanwhile, peri-urban agriculture is agriculture in the surrounding suburbs or urban areas. The peri-urban region has the characteristics of rapid agricultural development, is very intensive, and has a commercial orientation to provide jobs in large numbers [9]. The peri-urban areas in Bandung Metropolitan include: Bandung Regency, West Bandung Regency, and Sumedang Regency.

The basis for determining areas included in intra and periurban agriculture in Bandung Metropolitan refers to research conducted by Budiyantini and Pratiwi [37] related to periurban areas in Bandung Metropolitan, which are divided into three clusters with physical, social, and economic characteristics.

Based on the grouping of peri-urban areas in Bandung Metropolitan, it can be understood that some areas of Bandung Regency, West Bandung Regency and Sumedang Regency are included in peri-urban areas.

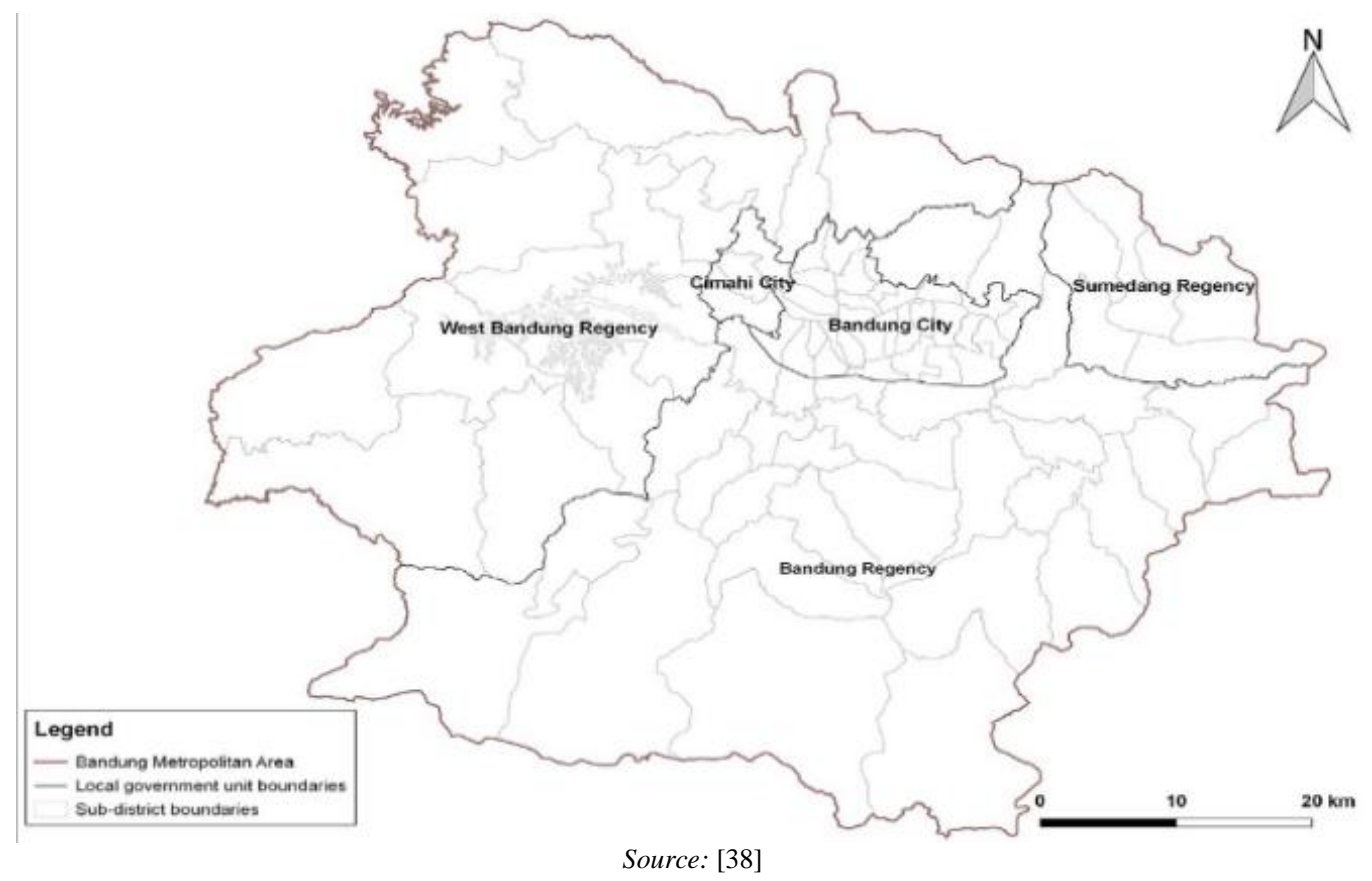

Figure 1. Location of Bandung metropolitan, West Java, Indonesia 


\subsection{Informant determination}

Informants were actors operating on a subsistence, semicommercial, or commercial scale in urban agriculture activities. In this study, informants were chosen using a purposeful technique. Additionally, the informant retrieval technique employs the snowball technique, in which researchers obtain information about suitable informants by rolling from one informant to the next. Snowball sampling can be used with various informal methods that use identified social networks to identify a growing set of potential contacts $[39,40]$. However, various problems might develop during the snowball data gathering process, such as selection bias, which reduces the sample's validity [40-42].

Therefore, we did not use snowball as the dominant sampling technique in this study. We used the snowball technique to identify actors who were not farmer group administrators but had a significant role in the farmer's group. To avoid selection bias, we used snowballs for actors in the intra-group and used the snowball technique by developing a network perspective from external institutions, such as local governments and field technical assistants from the agricultural service. We also used stratified purposeful sampling. This sampling captured the variation in the manifestation of a phenomenon because each key factor associated with the phenomenon varies [43]. We conducted a stratified purposeful sampling based on many urban farmer groups in Bandung Metropolitan. Therefore, we took farmer groups in each subsistence, semi-commercial and commercial cluster by considering the representativeness of the combination of the four aspects that we examined based on market-orientation level. We studied farmers' groups with different cases in four aspects: the farmer's objective, sources of inputs, product mix, and household income. The study gathered 50 informants. We concentrated on group representation. We selected three groups from each category of urban agriculture (Subsistence, Semi-Commercial, and Commercial) that contained comprehensive data on four aspects of market orientation. Each group was represented by four farmers. Thus, each of the subsistence, semi-commercial, and commercial urban farmers had twelve informants. While the other fourteen informants were from local government institutions and exporters of urban agricultural products. The number of informants was determined based on data saturation, when there was no new information or data resulting from the addition of informants.

\subsection{Data collection}

We conducted observations at urban farming sites in intraurban and suburban areas that were the basis for subsistence, semi-commercial, and commercial agriculture. The researchers observed how farmers carried out food crop and horticultural production activities and observed urban agriculture marketing networks oriented towards subsistence, semi-commercial and commercial. Researchers interviewed 50 informants, consisting of local government, subsistence, semi-commercial, commercial farmers, and exporters. Researchers collected data through a compilation of photo files, documents, videos, and sound recordings. The researchers also collected secondary statistical data on agricultural land, commodity production value, and agricultural exports in Bandung Metropolitan. All of the informants have agreed to be informants in this study. We had official research permits, which we registered under the research licensing procedures by local government agencies.

\section{RESULTS AND DISCUSSION}

\subsection{The existence of subsistence urban agriculture in Bandung metropolitan}

The subsistence urban agriculture model has the aim of fulfilling daily food needs. Based on the source of its formation, the subsistence urban agriculture model activities in Bandung Metropolitan could be classified into two types; urban agriculture formed by the local government and civil organizations. Both have different activity patterns because they originated from different sources and missions. Below was an identification of the urban subsistence farming model established by the local government and urban agriculture which independent civil organizations formed.

\subsubsection{Farmer's objective}

In Bandung Metropolitan, urban agriculture was primarily concentrated in intra-urban regions. Encourage urban agricultural projects to alleviate the reliance on food from suburban areas because of the high food demand in intra-urban areas. This situation was represented in Bandung City's urban agricultural program. Before implementing urban agriculture, it was difficult for the Bandung City government to develop conventional agriculture. As a result, reliance on peri-urban food supply sources was relatively high. Therefore, this phenomenon was dubbed a policy failure, as the agricultural programs initiated by the Bandung City government were unable to meet the city's food needs.

The City Government's Department of Food and Agriculture responded to the fulfillment of autonomous food demands through top-down urban agricultural innovation. Since 2014, the Bandung City Government, through its Department of Food and Agriculture, has been implementing an urban gardening program to reduce reliance on food sources from outside the city (see Figure 2). The scheme was conducted by repurposing vacant or formerly residential property near the urban communities. Currently, the Bandung City Government oversees 192 urban agricultural groups.

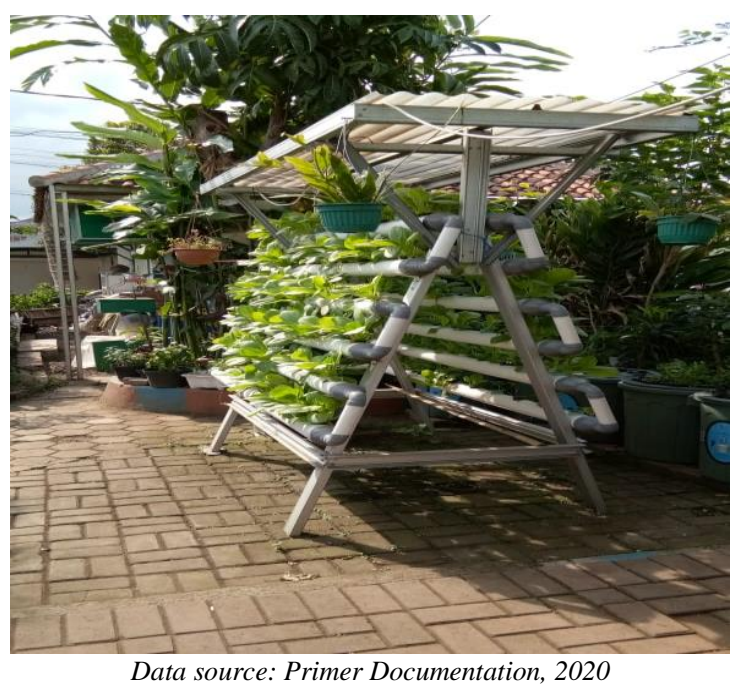

Figure 2. Subsistence-urban agriculture group by local government 
The Department of Food and Agriculture of Bandung City initiated an urban agriculture program to meet household needs for fresh vegetables. Therefore, the Department of Food and Agriculture Office of Bandung City did not project urban agriculture as a replacement for the city community's livelihood, but rather to actualize a healthy lifestyle and reduce food dependency from other regions. The dependency on food supply from other regions could cause food market inflation.

Most members formed by the Department of Food and Agriculture were interested in urban agriculture groups to pursue hobbies. This motivation was susceptible to discontinuity because not all participants had an interest in urban agriculture. Therefore, several urban agricultural groups found without members interested in continuing the initiative. The Department of Food and Agriculture evaluated the urban agriculture group's implementation effectiveness. They would eliminate urban agriculture groups that were no longer operational from the list of beneficiaries.

Meanwhile, independent urban agriculture aimed critical awareness of vegetable and fruit products on the market that contained artificial pesticides that were harmful if consumed in the long term (see Figure 3). According to the results of an interview with a subsistence farmer engaged in urban agriculture, he was skeptical about vegetable goods found in supermarkets. Many other farmers in conventional agriculture used pesticides and non-organic fertilizers to achieve the volume of product that should be deposited and the quality of leaves without the holes. Some unethical vegetable supplier farmers in supermarkets used NPK and urea fertilizers to maximize production at a low cost, time, and energy investment. Based on this knowledge, urban subsistence farmers engaged in urban agriculture by promoting nutritious vegetables and fruits that were previously unavailable on the market. It demonstrated that the market failed to ensure healthy food security and was devoid of inorganic pesticides in families, particularly vegetables. Thus, a combination of organic and inorganic items might circulate and be promoted in supermarkets.

Another reason for independent urban groups to engage in urban agriculture subsistence was to save money on household expenses. Subsistence urban farmers could save between IDR 300,000.00 (USD 20.3) and IDR 100,000.00 (USD 6.79) each month by engaging in urban agriculture activities. Subsistence urban farmers supplied three grocery stores near their homes daily, earning an average of IDR 150,000 (USD 10) per day on vegetables priced at IDR 5,000 (USD 0.3) per bunch.

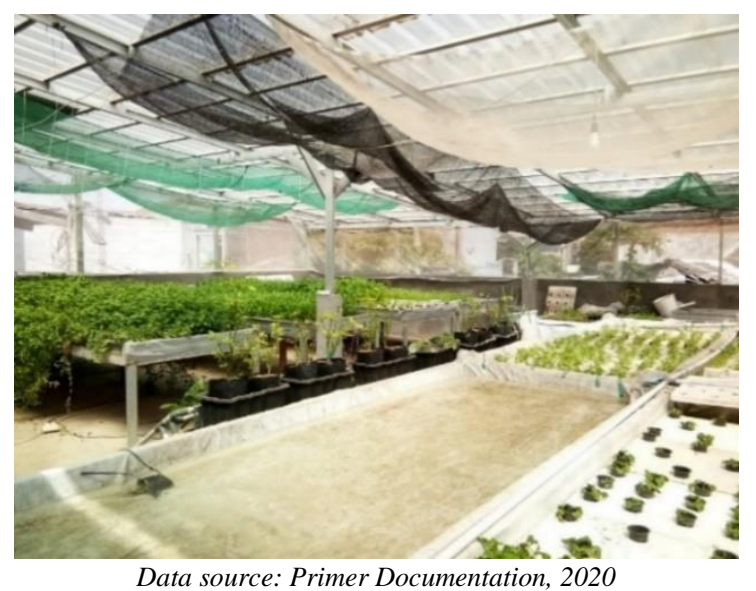

Figure 3. Subsistence-urban agriculture group by civil society organization

\subsubsection{Sources of inputs}

The urban agriculture group driven by the local government was utilizing planting facilities, hydroponic installation, and greenhouse construction. Local governments in five regencies/cities in Bandung Metropolitan also assisted the group according to their needs. For example, the Department of Food and Agriculture gave seedlings, nurseries, and fish ponds to the Subsistence Women's Farmer Group. The subsistence group used part of the local government-owned land, part of the land leased with aid from the local government, and part of the land granted to one member for internal subsistence farming. Additionally, urban subsistence farmers produced organic insecticides from animal manure. For fertilizer, some members occasionally purchased synthetic fertilizers.

The independent urban agriculture community processed vegetable pesticides to eradicate plant pests. The pesticide can be made from consumable foods, such as shallots (Allium ascalonicum), garlic (Allium sativum), ginger (Zingiber officinale), turmeric (Curcuma longa), binahong (Anredera cordifolia), and aloe vera (Aloe barbadensis miller). The ingredients were mashed and sprayed on plants to kill pests. Meanwhile, the non-organic pesticide had a chemical binding agent that could decay in three months. Plant nutrition came from the decomposition results of rabbit urine, leftovers, and remaining fruits that could be saved for 5-7 years. However, not all urban agriculture actors were aware of the compounding of vegetable pesticides; many farmers still used artificial pesticides. Limited knowledge of urban agriculture management was a determining factor for the preference of urban farmers to implement environmentally friendly and healthy production. The knowledge related to organic treatment intervention was also crucial to minimize the production cost of fertilizer and pesticides.

\subsubsection{Product mix}

Hydroponic, verticulture, and aquaponic production methods were applied to subsistence urban agriculture by the local government and independent civil society organizations. Chilies (Capsium frutescens), kale (Ipomoea aquatica), mustard greens (Brassica juncea), strawberries (Fragaria ananassa), and tomatoes (Solanum lycopersicum) are the vegetables produced by subsistence urban agriculture. The local authorities directed them to plant a certain of crops, but the plants were chosen through communal consensus. Customer demand dictated the plant types used. The consumers were neighbors and those who frequently went through the urban farm region. Customers' favorite vegetables are kale (Ipomoea aquatica) and mustard greens (Brassica juncea). Kale (Ipomoea aquatica) and mustard greens (Brassica juncea) were crops that urban subsistence farmers mainly produced because they were consumables required for household nutrition and were highly sought after by local consumers. It was demonstrated by the five-year trend of increased production of kale (Ipomoea aquatica) and mustard greens (Brassica juncea) in intra-city areas such as Bandung and Cimahi.

The city government frequently encouraged urban agriculture programs in intra-urban agriculture by offering hydroponic installation and greenhouses support. This installation can be used to grow horticulture crops, particularly kale (Ipomoea aquatica) and mustard greens (Brassica juncea). As a result, most urban farmers selected kale (Ipomoea aquatica) and mustard greens (Brassica juncea), even though 
these two vegetables were not very durable. The perishability of the two veggies, on the other hand, was not an issue because they were utilized for household purposes and had a short marketing chain. Along with veggies and seeds, the subsistence urban agriculture organization sold processed products such as red spinach chips, peanut brittle, and vegetable juices. The marketing approach was utilized to supply recipes for food processing in order to attract consumers. Members of the urban agricultural group involved in sales operations used the slogan "Quality above supermarkets, cost below supermarkets" as an effective marketing tactic for attracting clients. They used professional packaging for their products, just like vegetables in supermarkets.

\subsubsection{Household income sources}

Farmer households did not feel the economic gains because the focus was on ensuring each member's food security. The benefits created by urban agriculture operations also resulted in a decrease in household expenses. Not only did these subsistence urban agricultural groups consumed their output, but they also processed harvest products.

The vegetable harvest's sales revenues were included in the urban agricultural group's income. The income earned by the urban agriculture group was variable. The subsistence urban farmer group that assisted by the Local Government got an average of IDR 1,155,000 (USD 81.21) value of urban agriculture production per household/season. The revenue was generated by selling products such as red ginger (Alpinia purpurata) and pakcoy (Brassica rapa). They sold veggies at an average price of IDR 15,000-20,000 (USD 1.05-1.40) per kilogram during the 10-15-day harvesting season. The subsistence urban farmer group's primary objective was not to earn money but to operate operational costs. Harvesting and product sales were used to support the community capital's production and to cover costs of community events such as independence celebrations, rituals, and Ramadhan event.

The local government tried various strategies to stimulate urban people's interest in planting, including organizing gardening products. In Bandung City, there was an exhibition and distribution of plant seeds through the Bandung Agri Market. The Bandung Agri Market was a marketing platform for harvests and MSME products produced by the urban agricultural group operating under the authority of the Bandung Department of Food and Agriculture. The Bandung Agri Market was designed to inspire enthusiasm in members of the urban agricultural group founded to sustain their group's production efforts.

Independent subsistence urban agriculture generated income for households ranging from IDR 1,500,000 to IDR $4,500,000$ (USD 105.48 to 316.43 ) every season. The revenue was used to fund the next round of production, while households used the profits to purchase non-produced necessities. The independent urban agriculture community cultivated a plot of land surrounding the living setting by utilizing the front yard, back yard, and balcony. One example of subsistence urban agriculture was practiced on governmentowned unoccupied land. The group constructed two greenhouses on vacant government-owned land surrounding their residence, measuring $3 \times 6 \mathrm{~m}^{2}$ and $4 \times 6 \mathrm{~m}^{2}$.

Capital for independent urban agriculture came from cooperative community members and bank funding. Capital issued by urban agriculture farmers in the independent community depended on each farmer's creativity in allocating available resources. In one instance, the issued fund reached IDR $10,000,000$ to construct a greenhouse for a subsistence group (USD 703.18). It was because they utilized the urban agricultural group's self-designed pipes. Other independent urban agricultural communities spent between IDR 25,000,000-IDR 50,000,000 (USD 1757.94-3515.88) on constructing the greenhouse and hydroponic installation. Thus, the independent community's critical feature to reduce operational costs was recycling second-hand materials into productive types of materials.

\subsection{The existence of semi-commercial urban agriculture in Bandung metropolitan}

Urban agricultural activities generated new economic opportunities from existing sources of income. A part of urban agriculture that was initially carried out in subsistence orientation began to gain economic benefits. It triggered the emergence of urban agriculture, transforming it into a semicommercial scale. However, the emergence of semicommercial urban agriculture was born out of a growing subsistence group towards business. Semi-commercial groups emerged from urban civil society movements that formed social, environmental, and economic missions.

\subsubsection{Farmers objective}

Urban agriculture-based semi-commercial scale in Bandung Metropolitan has the primary mission of improving environmental conditions by utilizing vacant land in urban areas, education, and outreach community to implement urban agricultural activities (Figure 4). Therefore, urban farmers on a semi-commercial scale formed sociopreneur groups to realize multifunctionality in agricultural activities. Semicommercial groups tried to create a balance of functions in urban agriculture. Recently, some urban farmer groups on semi-commercial scale use the concept of edu-tourism. The concept of edu-tourism is to combine the concepts of urban agricultural education and tourism with the interest in maximizing productivity.

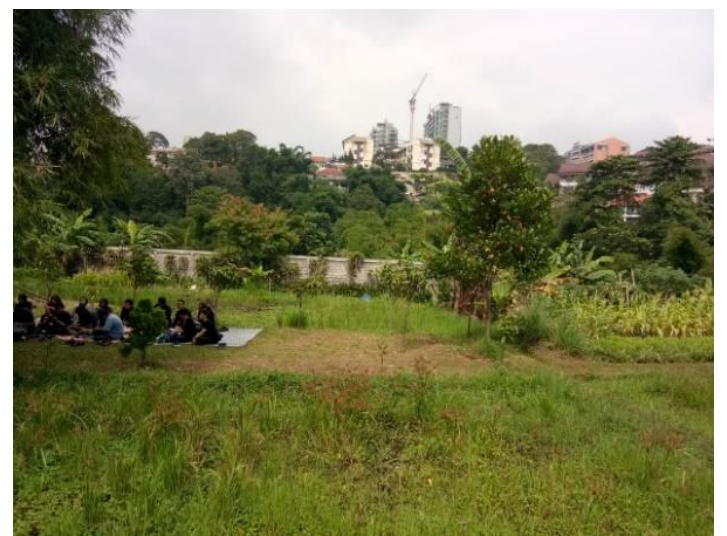

Data source: Primer Documentation, 2020

Figure 4. Semi-commercial urban agriculture group

However, the semi-commercial scale urban farmer groups were making efforts to develop a market expansion. They created social networking patterns with consumers, producers, investors, and local governments to expand their market. Social networks for consumers were developed to expand the market. One of the semi-commercial farmers stated they carried out marketing strategies through the WhatsApp group, 
community groups, and shop customer groups by inserting education and sharing knowledge of organic products to attract buyers.

\subsubsection{Sources of inputs}

Fertilizers, pesticides, and herbicides were obtained from purchases on a local scale. However, we found the case that semi-commercial farmers did the production of farmyard manure and seed cultivation. Semi-commercial urban agriculture needed agricultural equipment and human resources to operate their multifunctional activities. So, the actors needed economic capital. Economic capital was an essential element for developing economic activity. This aspect was a form of investment to get high-profit value. The initial source of capital for semi-commercial agriculture came from contributions from internal members and international donor agencies. Economic capital was used in land development and plantation operations. One urban farmer group in this research used economic capital to build outlets.

The establishment of outlets (organic stores) was a critical component of marketing support. Thus, economic capital was a necessary component of rising economic activity. It was a method of investing in order to obtain a large profit margin. The trend of community-based urban agriculture had a distinct technique for market attraction. They used a blue ocean strategy in order to differentiate themselves from the competition. The term "blue ocean strategy" refers to the process of establishing an unbeatable market region free of competitors in order to maximize profit [44]. Market creation was also used to help the urban agriculture business group increase economic capital. The business group created the market by investing in products with a high retail value and being relatively uncommon.

\subsubsection{Product mix}

Several informants stated that the products that were produced included telang flowers (Clitoria ternatea), stevia (Stevia rebaudiana), mint (Mentha), lemons (Citrus limon), and oranges (Citrus Sinensis). These commodities had various benefits, so the demand was relatively high. Besides, particular commodity investments, such as herbal plants, were also frequently found in urban agriculture cases implementing semi-commercial-oriented. It was caused by Bandung society's interest in consuming herbal products to treat diseases. The herbal products came from a particular type of plant. Some people have an awareness of planting highefficacy herbal plants in their home yard. Therefore, an urban agriculture community appeared in Bandung City to specially produced herbal plants because of the demand for herbal products consumed. The conversion of commodity types that were planted would be adapted to the market situation. The commercial orientation has blurred the meaning of urban agriculture as an endeavor to achieve food security.

Occasionally, semi-commercial groups did not generate their own products. Because they were multifunctional in their activities, they could boost production by establishing networks of other producers. Semi-commercial groups carried out network expansion to ensure product availability. Some semi-commercial urban farmers were committed to strengthening local food security by depositing organic and environmentally friendly commodities. The semi-commercial group conducted a survey on the production site to ensure that producer partners adopted organic and environmentally friendly techniques.
One informant said it was quite challenging to get a network of producers who applied organic products because not all producers had attention to organic and environmentally friendly principles. For this reason, they often experience shortages of products. Besides, relations with producers often experienced misperceptions where shipments of goods made by producers often ignored technical aspects, such as the time of harvest and the characteristics of products, MSMEs that did not include price barcodes, expiration dates, and labeling.

In marketing, the primary intention was to focus on product quality. To get consumers trust, they provided consumers with prototype products. Consumers could compare farmer-owned products with those of other farms. Therefore, the consumers will have product knowledge. Farmers should socialize product prototypes by giving them away to as many potential customers as possible and educating them about organic products' benefits. The mechanism was a market that followed farmers and set prices without product promotion. The consumers would pay a visit to the garden and select the products produced there. The semi-commercial urban agricultural groups also should understand the market's characteristics, how producers followed the market, and how producers could create distinctive products. They should consider the target market, plant characteristics, market objects (supermarkets or local markets), and seasonal planting patterns.

\subsubsection{Household income sources}

Crop productivity on a semi-commercial scale in a limited land area could not be a source of income. Price instability was a significant element since it encouraged urban farmers to examine ways to raise revenue from agriculture. Internalizing certain features of urban agriculture services was one strategy for getting income. Internalizing the value of services was one of the diverse business models used in urban agriculture. Therefore, many semi-commercial urban agriculture has transformed into urban agriculture based on edu-tourism. Thus, the revenue generated by urban agriculture based on edu tourism was supported by other productive economic sectors, including food production, rental of space for various activities, gardening packages, knowledge of nature packages, archery packages, and camping packages. In urban agriculture based on edu-tourism, there was an entry ticket. Commercialization of urban agriculture was necessary to ensure community sustainability. It was because urban agriculture groups needed continual economic resources to improve the business aspects of urban farm operations.

Landowners, farmers, PICs (Person in Charge), intermediaries, and tourists were actors who involved in semicommercial urban agriculture based on edu-tourism. They could earn between IDR 1,500,000 and IDR 10,500,000 (USD $105.74-740.17)$ per season, depending on their organizational status. Landowners were actors who owned land resources. They rented their land to an edu-tourism management firm, which will handle it profitably. PICs (Person in Charge) were actors who were responsible for production and service activities. PICs implemented the production system by hiring landless farmers to manage the gardens. The farmers would market the crops through brokers. They produced the crops to meet Bandung City's vegetable and fruit needs. Visitors were actors who benefited from the Edu-tourism sector's offerings. Most visitors to edu-tourism were students on research trips organized by local schools and community groups interested in agriculture. 


\subsection{The existence of commercial urban agriculture in Bandung metropolitan}

Commercial urban agriculture sought to provide domestic and worldwide markets. Economic opportunities created by urban agricultural management inspired farmers to pursue company development. Capital ownership causes continuous geographic expansion for those who own capital, as their productive capability grows considerably faster than demand [45].

\subsubsection{Farmers objective}

Commercial urban agriculture, mainly for export, arose due to the creation of globally structured food policies. At the global level, political economy policy processes have resulted in a neoliberal international trade order. Thus, the economic growth paradigms of many countries were oriented toward boosting the value of food product export transactions. This situation developed as a result of third world countries' reliance on the international loan system established by IMF and World Bank institutions during the 1990s monetary crisis. Consequently, debtor countries must liberalize their economies in a variety of sectors, including agriculture, which was one of the primary conditions for implementing the Structural Adjustment Program (SAP) in developing countries.

The government used some measures to maintain a balance of commerce between export and import activities. As a result, regions such as Bandung Metropolitan were encouraged to continue developing urban agriculture on an export scale. The Indonesian Government accepted the World Trade Organization Agreement by enacting Law No. 7 of 1994. By ratifying, the Indonesian government consented to the WTO's Agriculture Agreement (AoA), which was composed of three pillars: market access, domestic support, and export subsidies [46]. Many countries have adapted their export and import standards legislation to conform to World Trade Organization standards.

\subsubsection{Sources of inputs}

Commercial urban agriculture used many seeds, synthetic fertilizers, and pesticides that came from purchases from farm shops. Several urban farmers with commercial systems in Bandung Raya collaborated with companies that produced inputs. Commercial urban farmers ordered seeds, fertilizers, and pesticides in large quantities to directly supply the products to the farmers. Commercial-oriented urban agriculture has high land requirements (see Figure 5). Some urban farmers in Bandung Metropolitan expanded into periurban areas to operate more intensive agricultural production. Farmers could not develop commercial agriculture in intraurban areas because of high land value. Based on land use data in Bandung City in 2017, the land used for conventional agriculture was only 736 ha.

Therefore, several urban agriculture farmers expanded into peri-urban areas to diversify their agricultural export production. Commercial urban agriculture in the Bandung Metropolitan region is concentrated in the Bandung Regency and West Bandung Regency. Bandung Regency and West Bandung Regency have the highest land areas, as some of these locations have peri-urban features with prospective urban clusters. Compared to other peri-urban groups, one of the characteristics of potential urban clusters was a high proportion of agricultural land [37]. It could be suggested by an increase in the area planted with vegetables, which have markets ranging from local to international. Farmers engaged in commercial urban agriculture were required to produce large harvest amounts of hydroponic products using a minimum of 10,000 planting sites. Besides land ownership, farmers should be able to operate technology and machinery.

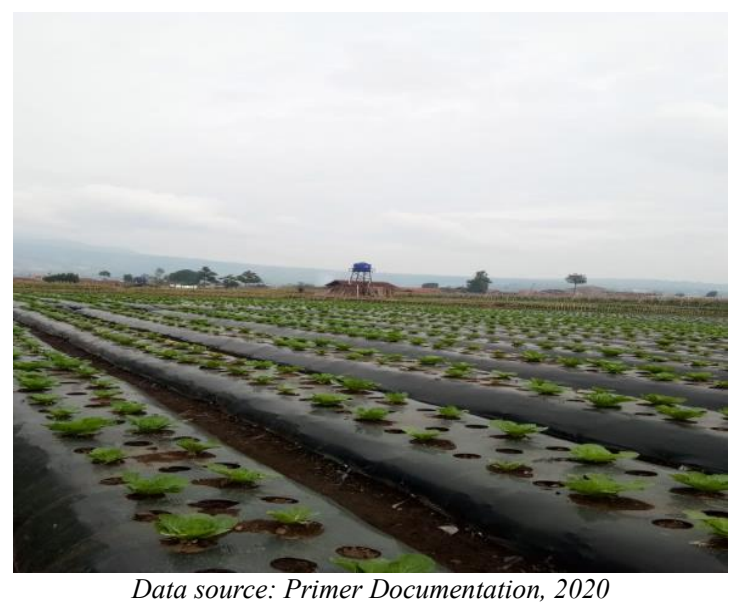

Figure 5. Commercial urban agriculture group

\subsubsection{Product mix}

Farmers produced food crops that exporters ordered. Farmers carried out a monoculture system in industrial agriculture to pursue the quantity of demanded crop commodities. It was because the cooperation contract contained the size of harvested products that farmers were required to fulfill. Therefore, the determination of the plant type to be planted by farmers for export was based on market demand.

Green beans (Phaseolus vulgaris) were the popular vegetable local to the international market. Compared to the other three regions of Bandung Metropolitan, West Bandung and Bandung Regencies had the highest planting areas for green beans (Phaseolus vulgaris).

It was because growing green beans (Phaseolus vulgaris) required suitable land. Bandung and West Bandung regencies were peri-urban areas conducive to growing green beans (Phaseolus vulgaris) than other locations. West Bandung Regency's land area increased over the last five years (20152019), reaching 577 hectares in 2019. Meanwhile, Bandung Regency planted 452 hectares of green beans (Phaseolus vulgaris) in 2019 (Based on Data Department of Food Crops and Horticulture West Java Province (2015-2019)).

The expansion of green beans (Phaseolus vulgaris) planting areas has impacted the production of green beans (Phaseolus vulgaris) commodities. The region that produced the highest of the five areas of Bandung Metropolitan was Bandung Regency, which reached 14,447 tons in 2019 (Based on Data Department of Food Crops and Horticulture West Java Province (2015-2019)). The production of green beans (Phaseolus vulgaris) in Bandung Metropolitan aimed to meet foreign markets. Therefore, urban agriculture that carried out green beans (Phaseolus vulgaris) cultivation activities was urban agriculture in peri-urban areas that had entered into the scale of commercial export production.

Farmers in West Bandung and Bandung Regency grew green beans (Phaseolus vulgaris) for the domestic and international markets. Producers in West Bandung and Bandung regencies used commodity green beans (Phaseolus vulgaris) to supply the Singapore market. 
However, the products were refunded that did not adhere to standard operating practices. Urban farmers may suffer losses if their product does not meet the exporter's specifications. Potential losses resulted from inequitable production interactions in which control products did not serve as the producer's authority. Commercial urban agriculture followed a strategy of bringing products to the traditional market that did not qualify for export. Farmers also developed relationships with vegetable sellers in traditional markets to sell products that did not meet export requirements. Thus, farmers could anticipate losses.

\subsubsection{Household income sources}

The export volume in January 2020 has increased significantly compared to January 2019. For horticultural commodities in February 2019, it only reached 88,413 tons, while in January 2020, it reached 1,173,057 tons (see Table 2). An increase in export volume also occurred in food plant commodities; in February 2019, it only reached 108,631 tons, while in February 2020, it reached 134,159 tons (see Table 2). The economic value generated from export trade activities also increased during the period from February 2019 to February
2020. The economic value of horticultural commodities in February 2019 reached IDR 4,223,737,480 (USD 296,975) while in February 2020 it reached IDR 482,012,996,315 (USD $33,885,720)$. Meanwhile, the value of food crop commodities reached IDR 2,123,679,376 (USD 149,336) while in February 2020 it reached IDR 4,209,121,040 (USD 295,984) (Based on Data Agricultural Quarantine Agency of West Java Province, 2020).

Export farmers' income was highly variable and unpredictable from season to season. This condition was determined by the commodity's type, land area, overall production expenses, and external considerations such as crop failure caused by extreme weather. However, our interviews revealed that farmers with less than 1 hectare of land typically earn between IDR 3,000,000-10,000,000 (USD 210-703) per household/season. Meanwhile, farmers with a land size of two hectares reached between IDR 10,000,000-20,000,000 (USD 703-1406) per household/season. Farmers with over 3 hectares of land typically earned more than IDR 20,000,000 (USD 1406) per household/season. Additionally, farmer income fluctuated due to market factors affecting the selling price of agricultural commodities.

Table 2. Export volume and economic value of agriculture

\begin{tabular}{ccccc}
\hline & \multicolumn{2}{c}{ Export Volume (Tons) } & \multicolumn{2}{c}{ Economic Value (IDR) } \\
\cline { 2 - 5 } & $\begin{array}{c}\text { February, } \\
2019\end{array}$ & February, 2020 & February, 2019 & February, 2020 \\
\hline Horticulture & 88.413 & 1.173 .057 & 4.223 .737 .480 & 482.012 .996 .315 \\
\hline Crops & 108.631 & 134.159 & 2.123 .679 .376 & 4.209 .121 .040 \\
\hline Source: & Agricultural Quarantine Agency of West Java Province, 2020
\end{tabular}

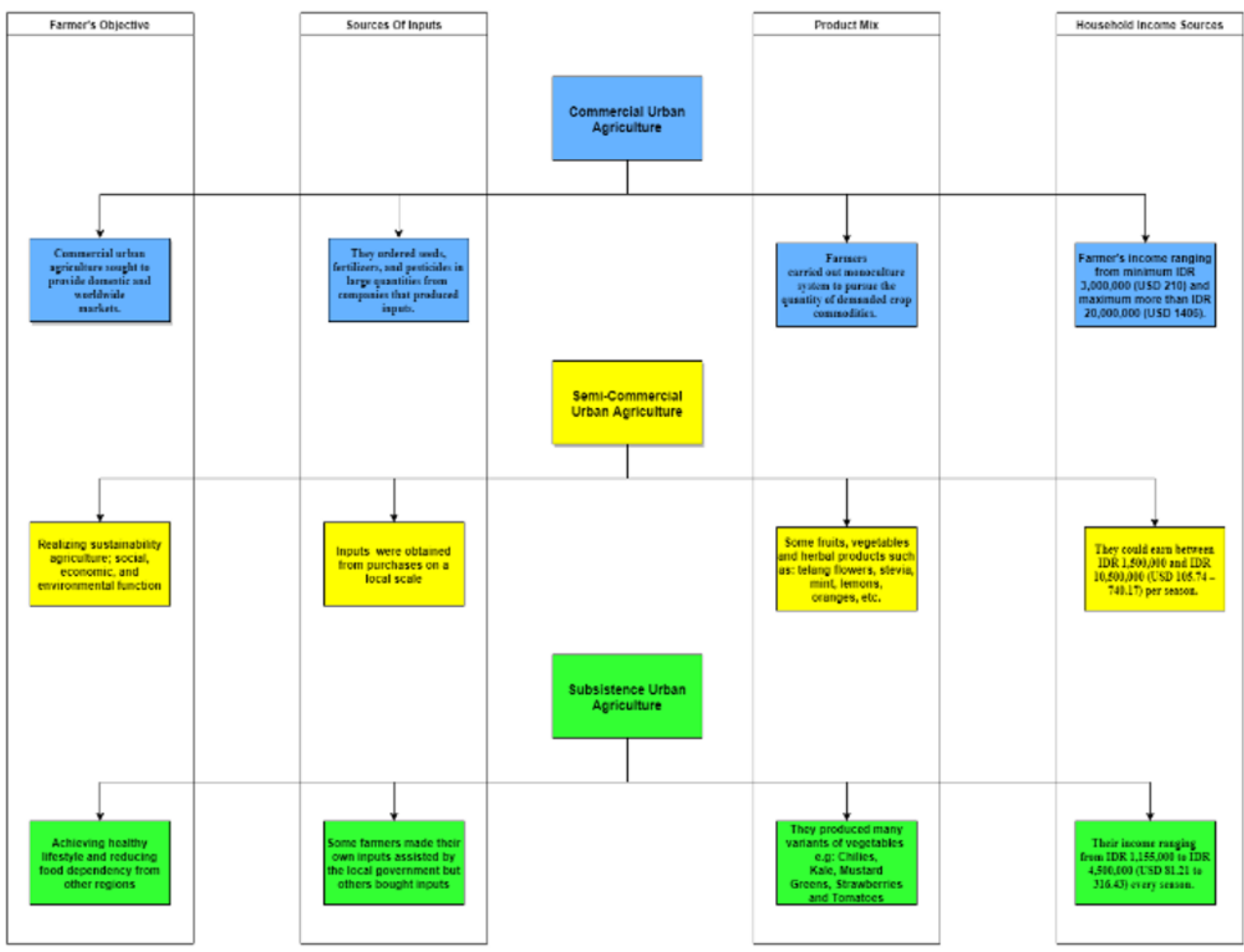

Source: Primer Documentation, 2020

Figure 6. Diagram framework of urban agriculture in Bandung metropolitan 


\section{CONCLUSIONS}

Urban agriculture became a solution to urban population problems related to fulfilling food needs, poverty, and limited green open space. The dynamics in urban agricultural activities presented a shift in goal orientation. This condition was characterized by segmented urban agriculture based on the level of market orientation (see Figure 6). This phenomenon also occurred in Bandung Metropolitan. Subsistence agriculture in Bandung Metropolitan has developed a lot in the intra-city area, including Bandung City and Cimahi City. Subsistence agriculture developed due to urban agricultural programs initiated by the city government. In addition, subsistence agriculture also arose from a civil society movement that had an interest in environmental issues related to food consumption. Semi-commercial agriculture in Bandung Metropolitan arose from the awareness of the multifunctionality of urban agriculture, which was captured as an opportunity by some urban farmers. The main motive of semi-commercial agriculture was to optimize urban agricultural activities in three aspects: Social, environmental, and economic. Commercial urban agriculture occurred because of agricultural changes to achieve maximum profit. Some urban farmers expanded their land in peri-urban areas to enter into agricultural export production. Agricultural development in the peri-urban areas of Bandung Metropolitan, including West Bandung regencies and Bandung regencies.

In subsistence urban agriculture, farmer households produced inputs. The Department of Food and Agriculture has trained many subsistence urban farmers in Bandung Raya in each region to conduct seed cultivation, make organic fertilizers and insecticides. Some semi-commercial urban farmers produced their inputs, but others chose to buy agricultural inputs. In comparison, commercial urban farmers purchased input supplies to optimize resources and manage time efficiently. Subsistence urban agriculture produced a wider variety of products than semi-commercial or commercial urban agriculture. In other situations, semicommercial agriculture that implemented the idea of edutourism also produced various crops, since urban farmers had grown a variety of crops to educate visitors about specific rare types.

Our findings showed that the primary source of household income from subsistence urban agriculture was nonagricultural activities, as urban subsistence farmers did not rely on urban agriculture as a stable source of revenue. Most urban subsistence farmers had a primary occupation other than agriculture, with agriculture operating as second employment. Semi-commercial agriculture earned money from agriculture and non-agriculture operations because it diversified activities, including the production sector and the service sector, particularly edu-tourism. Meanwhile, commercial agriculture's primary source of revenue was intensive agricultural production.

Our research showed that the characteristics of subsistence, semi-commercial and commercial agriculture reflected the city as a space that did not constrain farmers to carry out agricultural activities with various purposes. The classification of the three urban agriculture models interpreted the differences in the targets that urban farmers wanted to achieve in terms of social, environmental, and economic functions. Identifying the urban agricultural model in Bandung Metropolitan could be the foundation for developing urban agriculture as an alternative solution to improve food security, the economy, and environmental sustainability around the Upper Citarum Watershed. However, we found that marketoriented urban farms that met export standards had the mission to create high profits. Therefore, social and environmental functions were marginalized because of the application of intensive monoculture production systems.

The more commercial urban agriculture grew, the more efficient production became a priority for farmers, particularly the input procurement aspect. Commercial urban farmers will purchase additional inputs from other sources to efficiently manage their time, energy, and money. Farmers did not purchase local inputs, particularly seed breeding, to conserve local seed variations. Additionally, reliance on pesticides and synthetic chemical fertilizers drove urban farmers to engage in unsustainable agro-industrial food production techniques. The phenomenon has a detrimental effect on the sustainability of the environment. The projected development of urban agriculture, which initially aimed to reduce environmental damage in the Upper Citarum watershed, was challenging to achieve. Thus, from these findings, the concept of sustainability from the development of commercialized urban agriculture needed to be of public attention and became a complex issue to be discussed in further studies. So, the research can make contribution to formulate policy recommendations related to environmentally friendly urban agricultural management and capable of being a mechanism to achieve the targets of the Sustainable Development Goals.

\section{ACKNOWLEDGMENT}

The authors would like to thank the Rector of Universitas Padjadjaran, the contributions of research participants in Bandung City, West Bandung Regency, Bandung Regency, Sumedang Regency and Cimahi Regency. Funding for this research was supported by the Academic Leaderships GrantUniversitas Padjadjaran.

\section{REFERENCES}

[1] De Bon, H., Parrot, L., Moustier, P. (2010). Sustainable urban agriculture in developing countries. A review. Agronomy for Sustainable Development, 30(1): 21-32. https://doi.org/10.1051/agro:2008062

[2] Lynch, K. (2005). Rural-Urban Interaction in the Developing World. Taylor \& Francis

[3] Smit, J., Nasr, J., Ratta, A. (1996). Urban Agriculture: Food, Jobs and Sustainable Cities. New York, USA, 3537.

[4] Gwetsayi, R.T., Dube, L., Mashapa, C. (2016). Urban horticulture for food security and livelihood restoration in Mutare City, Eastern Zimbabwe. Greener Journal of Social Sciences, 6(3): 56-64. http://doi.org/10.15580/GJSS.2016.3.082116130

[5] Kutiwa, S., Boon, E., Devuyst, D. (2010). Urban agriculture in low income households of Harare: An adaptive response to economic crisis. Journal of Human Ecology, 32(2): 85-96. https://doi.org/10.1080/09709274.2010.11906325

[6] Tacoli, C. (1998). Rural-urban interactions: A guide to the literature. Environment and Urbanization, 10(1): 147166. https://doi.org/10.1177/095624789801000105

[7] Konijnendijk, C.C. (1999). Urban forestry in Europe: A 
comparative study of concepts, policies and planning for forest conservation, management and development in and around major European cities. https://www.wur.nl/en/Publication-

details.htm?publicationId=publication-way-3631393738.

[8] Heisler, G.M., Grant, R.H., Grimmond, S., Souch, C. (1995). Urban forests - cooling our communities. In Proceedings of the Seventh National Urban Forest Conference, Washington, DC: American Forests, pp. 3134.

[9] De Zeeuw, H. (2004). The development of Urban Agriculture; some lessons learnt. In Keynote paper for the International Conference Urban Agriculture, AgriTourism and City Region Development, Beijing: RUAF.

[10] Rees, W.E. (1997). Why urban agriculture? Notes for the IDRC Development Forum on Cities Feeding People: A growth industry. Vancouver, BC. http://www.cityfarmer.org/rees.html.

[11] Kem, S. (2017). Commercialisation of smallholder agriculture in Cambodia: Impact of the cassava boom on rural livelihoods and agrarian change. A Thesis Submitted for the Degree of Doctor of Philosophy, the University of Queensland in 2017.

[12] Linderhof, V., Janssen, V., Achterbosch, T. (2019). Does agricultural commercialization affect food security: The case of crop-producing households in the regions of postreform Vietnam? Sustainability, 11(5): 1263. https://doi.org/10.3390/su11051263

[13] Pingali, P.L., Rosegrant, M.W. (1995). Agricultural commercialization and diversification: Processes and policies. Food Policy, 20(3): 171-185. https://doi.org/10.1016/0306-9192(95)00012-4

[14] Cruz, M.C., Medina, R.S. (2003). Agriculture in the City: A Key to Sustainability in Havana, Cuba. Ian Randle Publishers.

[15] Monzote, F.F. (2008). Farming like we're here to stay: The mixed farming alternative for Cuba. PhD Thesis Wageningen University.

[16] Van Veenhuizen, R., Danso, G. (2007). Profitability and sustainability of urban and periurban agriculture, 19. Food \& Agriculture Org.

[17] Caouette, D., Turner, S. (Eds.). (2009). Agrarian Angst and Rural Resistance in Contemporary Southeast Asia (Vol. 4). Routledge.

[18] Hall, D. (2011). Land grabs, land control, and Southeast Asian crop booms. Journal of Peasant Studies, 38(4): 837-857. https://doi.org/10.1080/03066150.2011.607706

[19] Hall, D., Hirsch, P., Li, T.M. (2011). Introduction to Powers of Exclusion: Land Dilemmas in Southeast Asia. National University of Singapore Press and University of Hawaii Press.

[20] Li, T.M. (2014). Land's End: Capitalist Relations on an Indigenous Frontier. Duke University Press.

[21] Pingali, P.L. (2001). Environmental consequences of agricultural commercialization in Asia. Environment and Development Economics, 6(4): 483-502. https://doi.org/10.1017/S1355770X01000274

[22] Guthman, J. (2010). Excess consumption or overproduction? US farm policy, global warming, and the bizarre attribution of obesity. Global Political Ecology, $65-80$.

[23] Balcha, Y. (2013). Prospects of transforming subsistence agriculture into sustainable livelihoods; a case-study of the Ribb sub-catchment, Ethiopia. Uppsala University.

[24] Davidova, S., Fredriksson, L., Gorton, M., Mishev, P., Petrovici, D. (2012). Subsistence farming, incomes, and agricultural livelihoods in the new member states of the European Union. Environment and Planning C: Government and Policy, 30(2): 209-227. https://doi.org/10.1068/c1195r

[25] Giurca, D. (2008). Semi-subsistence farming-prospects for the small Romanian farmer to choose between a "way of living" or efficiency. Agricultural Economics and Rural Development, 5(3-4): 215-230.

[26] Guttormsen, A.G., Roll, K.H. (2014). Production risk in a subsistence agriculture. The Journal of Agricultural Education and Extension, 20(1): 133-145. https://doi.org/10.1080/1389224X.2013.775953

[27] Mohammed, A., Baze, M., Ahmed, M. (2016). Smallholder commercialization and commercial farming in coffee-spice based farming system of South West Ethiopia. International Journal of Research Studies in Agricultural Sciences (IJRSAS) Volume, 2: 13-26. http://dx.doi.org/10.20431/2454-6224.0205003

[28] Sambodo, L.A. (2007). The decision making processes of Semi-commercial farmers: A case study of technology adoption in Indonesia. Doctoral Dissertation, Lincoln University.

[29] Sibhatu, K.T., Qaim, M. (2017). Rural food security, subsistence agriculture, and seasonality. PloS One, 12(10): e0186406. https://doi.org/10.1007/s10457-0041023-y

[30] Nurysyifa, F., Kaswanto. (2019). Institutionalization of the citarum harum program in the management of the cirasea sub-watershed, upper citarum. Monograph of Agricultural and Environmental Policy Formulation of Strategic Studies in Agriculture and Environment, 6(3): 121-135. https://doi.org/10.29244/jkebijakan.v6i3.28064

[31] Utami, A.W. (2019). Kualitas Air Sungai Citarum. https://doi.org/10.31227/osf.io/m3ha2

[32] Moustier, P. (1999). Complémentarité entre agriculture urbaine et agriculture rurale. Urban Agriculture in West Africa: Contributing to Food Security and Urban Sanitation, 41-55.

[33] WinklerPrins, A.M. (Ed.). (2017). Global Urban Agriculture. CABI.

[34] Gonzalez, C.G. (2004). Trade liberalization, food security, and the environment: The neoliberal threat to sustainable rural development. Transnat'l L. \& Contemp. Probs., 14: 419.

[35] Spiaggi, E. (2005). Urban agriculture and local sustainable development in Rosario, Argentina: Integration of economic, social, technical and environmental variables. Agrop Soc Polit Environ Dimens urban Agric.

[36] Pearson, L.J., Pearson, L., Pearson, C.J. (2010). Sustainable urban agriculture: stocktake and opportunities. International Journal of Agricultural Sustainability, 8(1-2): 7-19. https://doi.org/10.3763/ijas.2009.0468

[37] Budiyantini, Y., Pratiwi, V. (2016). Peri-urban typology of Bandung Metropolitan area. Procedia-Social and Behavioral Sciences, 227: 833-837. https://doi.org/10.1016/-j.sbspro.2016.06.152

[38] OECD. (2016). Green Growth in Bandung, Indonesia. OECD Green Growth Studies, OECD Publishing, Paris. 
https://doi.org/10.1787/9789264264113-en

[39] Thompson, S.K. (1997). Adaptive sampling in behavioral surveys. NIDA Research Monograph, 167: 296-319.

[40] Atkinson, R., Flint, F., Gilbert, N. (2001). Snowball research strategies. Dep Sociol Univ Surrey Guildf GU2 $5 \mathrm{XH}$ United Kingdom. https://sru.soc.surrey.ac.uk/SRU33.PDF.

[41] Van Meter, K. (1990). Methodological and design issues: techniques for assessing the representatives of snowball samples. NIDA Research Monograph, 98(51.40): 31-43.

[42] Kaplan, C.D., Korf, D., Sterk, C. (1987). Temporal and social contexts of heroin-using populations: An illustration of the snowball sampling technique. Journal of Nervous and Mental Disease.

[43] Suri, H. (2011). Purposeful sampling in qualitative research synthesis. Qualitative Research Journal.

[44] Kim, W.C., Mauborgne, R. (2014). Blue Ocean Strategy, Expanded Edition: How to Create Uncontested Market Space and Make the Competition Irrelevant. Harvard Business Review Press.

[45] Giraldo, O.F. (2019). Political Ecology of Agriculture: Agroecology and Post-Development. Springer. https://doi.org/10.1007/978-3-030-11824-2

[46] Malian, A.H. (2004). International trade policy for Indonesian agricultural commodities. Agricultural Policy Analysis, 2(2): 135-156. https://doi.org/10.21082/akp.v2n2.2004.-135-156 